JOANNA GRZELAK ${ }^{1 *}$

JOANNA NIECZUJA-DWOJACKA

ANNA SINIARSKA

EWELINA SAMUL

\title{
Budowa i proporcje ciała warszawskiej młodzieży gimnazjalnej
}

\section{Summary \\ Body Build and Proportions of Warsaw Youth}

The aim of the study was to assess changes in body build of young Warsaw pupils during the last 14 years and coming from different living conditions and lifestyle. The material comprised youth attending high school (177 individuals) aged 14-16 years. The questionnaire form included parents' education, the number of: family members, offspring, rooms, daily meals; smoking habits of parents; assessment of physical activity and stress at home, school, and high school grades. Measurements included: height and weight, upper and lower extremity length, trunk length, arm, chest, waist and hip circumferences, three subcutaneous fat folds. BMI and WHR were calculated. The living conditions were reduced by principal component analysis to three factors (family size, living conditions, environmental stress). Regression analysis showed the relation of 3 factors to body build. The current youth were characterized by greater: weight, BMI, fat tissue, trunk length and body circumferences than their coevals 14 years before. In more numerous families youth had greater trunk length. In worse living conditions they were characterized by shorter legs and more fat tissue on arm. In stress conditions youth presented greater hip circumference.

1 Wydział Biologii i Nauk o Środowisku, Uniwersytet Kardynała Stefana Wyszyńskiego, ul. Wóycickiegol/3, Warszawa, * e-mail: j.grzelak@uksw.edu.pl 
Słowa kluczowe: rozwój somatyczny, trend sekularny, warunki bytowe. Key words: somatic development, secular trend, socioeconomic status.

\section{Wstęp}

Rozwój fizyczny dzieci i młodzieży i jego składowe takie jak: procesy wzrastania, tempo dojrzewania, proporcje ciała, samopoczucie i samoocena, są wykorzystywane do oceny zdrowia dzieci i młodzieży jako tzw. pozytywne mierniki stanu zdrowia (Przewęda 2009: 57-71, Wolański 2012: 7-11). Wyniki tego typu badań wykazują wieloletnie tendencje zmienności (trend sekularny) oraz reakcje młodego organizmu na zmieniające się warunki bytowe, gdyż rozwój człowieka od początku jego istnienia był ściśle powiązany $\mathrm{z}$ warunkami środowiskowymi (Wolański 2006: 347-348, 2012: 7-11).

Na przestrzeni ostatnich 100 lat obserwuje sie przyspieszenie rozwoju biologicznego człowieka, a co za tym idzie osiąganie większych wymiarów ciała. Zjawisko to jest szczególnie dobrze udokumentowane w przypadku wysokości i masy ciała (Malinowski 2002: 74-82; Radochońska, Perenc 2008: 142-155). Wśród głównych przyczyn trendu sekularnego wymienia się ulegające stałej zmianie warunki społeczno-ekonomiczne, zacieranie różnic społecznych, ekonomicznych i środowiskowych, zmiany nawyków żywieniowych i zjawisko heterozji (Wolański 2012: 86-90, 535-543).

Cechy somatyczne dziecka, jako pozytywne mierniki jego zdrowia i rozwoju, są wynikiem morfologicznej adaptacji organizmu do otaczającego środowiska. Korzystne lub niekorzystne wpływy środowiskowe modyfikują genetycznie uwarunkowany przebieg rozwoju, co wyraża się zmianami w wielkości i tempie wzrastania poszczególnych cech. Każdy organizm odpowiada na bodźce środowiskowe w sposób zróżnicowany, w zależności od jego ekosensytywności, siły działania danego bodźca, a także od określonej genetycznie zdolności przystosowawczej (adaptabilności). Efekt działania danych czynników zarówno zewnętrznych, jak i wewnętrznych znajduje swe odbicie w budowie ciała dziecka (Pawlińska-Chmara, Kulik-Nowak 2005: 45-50, Wolański 2012: 120-226). 
Przemiany cywilizacyjne, wzrost świadomości rodziców, wyższy poziom opieki medycznej oraz higieny życia codziennego stwarzają coraz lepsze warunki rozwoju i wychowania kolejnych pokoleń (Wolański 2012: 156-173). Powszechnie uważa się, że wyższy status ekonomiczno-społeczny (SES) sprzyja osiągnięciu większych wielkości cech somatycznych i akceleracji wieku dojrzewania (Wolański 2000: 191-209). Badania wielu autorów wskazują, że dzieci mieszkające $\mathrm{w}$ dużych miastach, pochodzące $\mathrm{z}$ rodzin małodzietnych, których rodzice posiadają wykształcenie co najmniej średnie, wykazują wyższy poziom rozwoju somatycznego w porównaniu do rówieśników, których odpowiednie warunki społeczno-ekonomiczne są gorsze (Pawlińska-Chmara, Kulik-Nowak 2005: 45-50). Wśród lokalnych grup można zaobserwować niejednorodne tempo zachodzących procesów społeczno-bytowych, które często uznawane są za jedną z głównych przyczyn zróżnicowania biologicznego ludności (Cieśla, Nowak-Starz 2007: 21-22).

\section{Cel pracy i hipotezy badawcze}

Celem niniejszego opracowania jest oszacowanie zmian budowy i proporcji ciała młodzieży warszawskiej w ciągu ostatniej dekady. Jako punkt odniesienia służyła praca Palczewskiej i Niedźwieckej (2001: 1-120). Ponadto badano różnice w budowie i proporcjach ciała między młodzieżą ze środowisk o różnych warunkach bytowych.

Hipotezy badawcze:

1. Budowa ciała współczesnej młodzieży gimnazjalnej różni się od budowy ciała młodzieży badanych przed 14 laty.

2. Młodzież pochodząca ze środowisk o zróżnicowanym statusie ekonomiczno-socjalnym wykazują różnice w budowie i proporcjach ciała.

\section{Materiał i metody}

Badania przeprowadzono w dwóch szkołach gimnazjalnych (nr 73 i 74) na terenie dzielnicy Bielany m.st. Warszawy w okresie od stycznia 
do maja 2012 roku. Badaną grupę stanowili uczniowie klas gimnazjalnych od 1 do 3, zarówno chłopcy jak i dziewczęta (Tab. 1). Ogółem zbadano 89 chłopców i 88 dziewcząt.

Tabela 1. Liczba zbadanej młodzieży w podziale na grupy wieku i płeć.

\begin{tabular}{|c|c|c|c|c|c|c|}
\hline \multirow[t]{2}{*}{ Wiek w latach } & \multicolumn{2}{|c|}{ Chłopcy } & \multicolumn{2}{|c|}{ Dziewczęta } & \multicolumn{2}{|c|}{ Ogółem } \\
\hline & $\mathrm{N}$ & $\%$ & $\mathrm{~N}$ & $\%$ & $\mathrm{~N}$ & $\%$ \\
\hline 14,00 & 34 & 38,2 & 36 & 40,9 & 70 & 39,5 \\
\hline 15,00 & 34 & 38,2 & 27 & 30,7 & 61 & 34,5 \\
\hline 16,00 & 21 & 23,6 & 25 & 28,4 & 46 & 26 \\
\hline Ogółem & 89 & 100 & 88 & 100 & 177 & 100 \\
\hline
\end{tabular}

Materiał niniejszej pracy stanowią informacje ankietowe i pomiary antropologiczne. Pytania skierowane do uczniów obejmowały dokładna datę i miejsce urodzenia i dotyczyły wykształcenia rodziców, warunków lokalowych, aktywności fizycznej (ocenianej przez częstość uczestnictwa w zajęciach sportowych: nigdy, raz w tygodniu, 2-3 razy z tygodniu, więcej niż 3 razy w tygodniu, codziennie), oceny własnej aktywności fizycznej (niska, średnia, wysoka), jak również liczby posiłków spożywanych w ciągu dnia. Pytania dotyczyły także oceny własnej poziomu stresu w domu i w szkole (niski, średni, wysoki), średniej ocen w szkole, palenia papierosów przez rodziców, a w przypadku odpowiedzi twierdzącej, czy dzieje się to w ich obecności.

Pomiary antropologiczne obejmowały: masę ciała, wysokość ciała (B-v w cm), wysokość suprasternale (B-sst w cm), długość kończyn dolnych (B-sy w cm), wysokość akromion (B-a w cm), wysokość daktylion III (B-daIII $\mathrm{w} \mathrm{cm}$ ); obwody $\mathrm{w}$ centymetrach: ramienia na wysokości brzuśca mięśnia dwugłowego ramienia, pasa i bioder oraz grubość fałdu skórno-tłuszczowego na ramieniu, pod łopatką i na brzuchu w mm. Wszystkie pomiary zostały wykonane zgodnie z obowiązującą techniką pomiarową (Malinowski, Wolański 1988: 128-134, 137-141, 149, Grzelak, Nieczuja-Dwojacka 2013: 10-13).

Na podstawie pomiarów obliczono:

- Długość kończyn górnych: [B-a] - [B-daIII] 
- Długość tułowia: [sst-sy]

- Wskaźnik długości kończyn górnych: (długość kończyny górnej $\mathrm{w} \mathrm{cm} /$ wysokość ciała $\mathrm{w} \mathrm{cm})^{\star} 100$

- Wskaźnik długości kończyn dolnych: (długość kończyny dolnej $\mathrm{w} \mathrm{cm} /$ wysokość ciała $\mathrm{w} \mathrm{cm})^{\star} 100$

- Wskaźnik długości tułowia: (długość tułowia w cm / wysokość ciała $\mathrm{w} \mathrm{cm})^{\star} 100$

- Wskaźnik międzykończynowy: (długość kończyny górnej w cm / długość kończyny dolnej w cm)*100

- BMI: ciężar ciała $[\mathrm{kg}] /(\text { wysokość ciała }[\mathrm{m}])^{2}$

- WHR: obwód pasa w cm / obwód bioder w cm

- Sumę grubości trzech fałdów skórno-tłuszczowych

Do opracowania statystycznego wykorzystano następujące metody:

W badaniach porównawczych wykorzystano badania warszawskie, prowadzone w latach 1996-1999 (Palczewska, Niedźwiecka 2001: 1-120). W tym celu dokonano standaryzacji pomiarów na dane Palczewskiej i Niedźwieckiej (grupa odniesienia), z uwzględnieniem płci i wieku, wg następującego wzoru:

$\mathrm{Z}=\frac{x \text { (wielkośćcechy badanegoosobnika })-\bar{x}(\text { średnia danej cechywg grupyodniesienia })}{s(\text { odchylenie statndardowe grupy odniesienia })}$

W części poświęconej wpływowi warunków bytowych na rozwój somatyczny i budowę ciała dokonano standaryzacji z wykorzystaniem średniej i odchylenia standardowego badanego materiału, w podziale na płeć i wiek.

Do oceny istotności statystycznej różnic w budowie i proporcjach ciała dziewcząt badanych obecnie i 14 lat temu zastosowano test dwustronny dla średnich niezależnych.

Zastosowano analizę głównych składowych, która pozwoliła na redukcję charakterystyk warunków bytowych do kilku niezależnych czynników. Następnie, analiza regresji liniowej w wersji krokowej, pozwoliła na ocenę związku wyodrębnionych czynników (zmienne niezależne) z budową ciała badanej młodzieży (zmienne zależne). 


\section{Wyniki}

\subsection{Budowa ciała młodzieży dziś i przed 14 laty}

W celu porównania wyników badań własnych (2012) z wynikami badań prowadzonych w latach 1996-1999 dokonano standaryzacji względem średniej i odchylenia standardowego z zewnętrznego układu odniesienia, jaki stanowią dane opublikowane przez Palczewską i Niedźwiecką (2001: 1-120) oraz obliczono istotność statystyczną różnic pomiędzy uzyskaną średnią, a układem odniesienia (gdzie średnia wynosi 0 , a odchylenie standardowe: 1). Ponieważ publikacja Palczewskiej i Niedźwieckiej nie zawiera wszystkich wziętych pod uwagę cech, ograniczono się jedynie do wymienionych w tabeli 2 .

Tabela 2. Wielkości badanych cech somatycznych w skali „z” względem średniej i odchylenia standardowego zewnętrznego układu odniesienia (Palczewska, Niedźwiecka 2001: 1-120) i ich istotność statystyczna.

\begin{tabular}{llcccc}
\hline Lp. & Cechy & $\mathbf{N}$ & $\overline{\mathbf{x}}$ & $\mathbf{S}$ & $\boldsymbol{P}$ \\
\hline 1 & Masa ciała & 177 & 0,60 & 1,45 & 0,0000 \\
2 & Wysokość ciała & 177 & 0,11 & 1,09 & 0,2037 \\
3 & Obwód ramienia & 177 & 0,74 & 1,47 & 0,0000 \\
4 & Długość kończyn dolnych & 177 & $-0,47$ & 1,23 & 0,0000 \\
5 & Wskaźnik długości kończyn dolnych & 177 & $-1,13$ & 1,58 & 0,0000 \\
6 & Długość tułowia & 177 & 1,32 & 1,51 & 0,0000 \\
7 & Wskaźnik długości tułowia & 177 & 1,73 & 1,83 & 0,0000 \\
8 & Fałd skórno-tłuszczowy na ramieniu & 177 & 0,68 & 1,93 & 0,0000 \\
9 & Fałd skórno-tłuszczowy pod łopatką & 177 & 1,53 & 2,53 & 0,0000 \\
10 & Fałd skórno-tłuszczowy na brzuchu & 177 & 2,71 & 3,08 & 0,0000 \\
11 & Suma trzech fałdów skórno-tłuszczowych & 177 & 1,93 & 2,63 & 0,0000 \\
12 & Wskaźnik masy ciała (BMI) & 177 & 0,66 & 1,57 & 0,0000 \\
\hline
\end{tabular}

Różnice istotne statystycznie stwierdzono w przypadku wszystkich badanych cech, z wyjątkiem wysokości ciała. Młodzież współczesna charakteryzuje się większą masą ciała i BMI, bogatszymi zasobami tkanki tłuszczowej, większą długością tułowia i wskaźnikiem długości 
tułowia oraz większymi obwodami ciała. Istotnie mniejsze okazały się: długość kończyn dolnych i wskaźnik kończyn dolnych.

4.2. Wpływ warunków bytowych na budowę i proporcje ciała młodzieży warszawskiej

Do oceny wpływu warunków bytowych na budowę i proporcje ciała młodzieży warszawskiej zastosowano analizę głównych składowych. Pozwoliło to na redukcję liczby zmiennych niezależnych (Tab. 3), opisujących warunki bytowe, poprzez łączenie ich w niezależne czynniki.

Tabela 3. Macierz składowych do analizy składowych głównych.

\begin{tabular}{llccc}
\hline Lp. & Zmienne niezależne & \multicolumn{3}{c}{ Składowa } \\
& & 1 & 2 & 3 \\
\hline 1 & Liczba osób w rodzinie & 0,73 & $-0,51$ & 0,10 \\
2 & Liczba rodzeństwa & 0,66 & $-0,55$ & 0,14 \\
3 & Liczba pokoi & 0,53 & 0,38 & 0,12 \\
4 & Oceny w szkole & 0,49 & 0,39 & 0,09 \\
5 & Aktywność fizyczna & 0,20 & 0,13 & $-0,15$ \\
6 & Wykształcenie wyższe i niższe & 0,41 & 0,56 & 0,12 \\
7 & Liczba dziennych posiłków & 0,15 & 0,48 & 0,28 \\
8 & Stres w szkole & $-0,21$ & 0,05 & 0,74 \\
9 & Stres w domu & $-0,18$ & $-0,26$ & 0,67 \\
10 & Dym tytoniowy & $-0,14$ & 0,03 & 0,36 \\
\hline
\end{tabular}

W wyniku zastosowania rotacji Varimax z normalizacją Kaisera, uzyskano macierz rotowanych składowych (Tab. 4). 
Tabela 4. Macierz rotowanych składowych metodą Varimax z normalizacją Kaisera.

\begin{tabular}{lccc}
\hline Zmienne niezależne & \multicolumn{3}{c}{ Składowa } \\
& 1 & 2 & 3 \\
\hline Liczba osób w rodzinie & 0,90 & 0,09 & $-0,07$ \\
Liczba rodzeństwa & 0,87 & 0,02 & $-0,002$ \\
Wykształcenie wyższe i niższe & $-0,05$ & 0,70 & $-0,05$ \\
Liczba pokoi & 0,17 & 0,63 & $-0,07$ \\
Oceny w szkole & 0,12 & 0,61 & $-0,09$ \\
Liczba dziennych posiłków & $-0,16$ & 0,51 & 0,19 \\
Stres w szkole & $-0,07$ & 0,09 & 0,77 \\
Stres w domu & 0,14 & $-0,14$ & 0,71 \\
Dym tytoniowy & $-0,06$ & 0,03 & 0,38 \\
Aktywność fizyczna & 0,04 & 0,19 & $-0,21$ \\
\hline
\end{tabular}

Analiza głównych składowych pozwoliła na wyodrębnienie 3 czynników (F1, F2, F3), wyjaśniających zmienność wszystkich zmiennych niezależnych opisujących warunki bytowe w około 46 procentach.

Pierwszy czynnik (F1) „wielkość rodziny” jest najsilniej dodatnio, skorelowany z liczbą osób w rodzinie i liczbą rodzeństwa, wyjaśnia zmienność w około $17 \%$.

Drugi czynnik (F2) „warunki bytowe” jest najsilniej dodatnio skorelowany z wykształceniem rodziców, liczbą pokoi w mieszkaniu (domu), ocenami w szkole i liczbą dziennych posiłków spożywanych przez ucznia, wyjaśnia zmienność badanych cech w około $16 \%$.

Czynnik trzeci (F3) „warunki stresowe” wykazuje najsilniejszą korelację ze stresem (w domu i szkole), narażeniem na dym tytoniowy i aktywnością fizyczną, wyjaśnia zmienność w około 13\%. Należy zwrócić uwagę, iż czynnik ten jest dodatnio skorelowany ze stresem i dymem tytoniowym, ale ujemnie $z$ aktywnością fizyczną badanej młodzieży. Oznacza to, że w przypadku stresowych warunków życia, aktywność fizyczna młodzieży jest mniejsza.

Następny etap pracy to zastosowanie analizy regresji liniowej w wersji krokowej, która pozwoliła na ocenę związku wyodrębnionych czynników z cechami budowy i proporcji ciała. Jedynie pięć badanych 
cech wykazuje zależność od wyodrębnionych czterech czynników środowiskowych. Wyniki analizy regresji przedstawiono w tabeli 5.

Tabela 5. Związek czynników z cechami somatycznymi i wskaźnikami budowy i proporcji ciała u młodzieży warszawskiej.

\begin{tabular}{|c|c|c|c|c|c|}
\hline $\begin{array}{l}\text { Cechy } \\
\text { somatyczne } \\
\text { i wskaźniki }\end{array}$ & $\begin{array}{l}\text { Czynnik i kierunek jego } \\
\text { związku ze zmienną } \\
\text { zależną }\end{array}$ & $\begin{array}{l}\text { Wsp. Beta } \\
\text { (standary- } \\
\text { zowany) }\end{array}$ & $\mathbf{T}$ & $\boldsymbol{P}$ & $\begin{array}{l}\text { \% wyjaśnia- } \\
\text { nej zmienno- } \\
\text { ści }\left(\mathrm{R} 2^{\star} 100\right)\end{array}$ \\
\hline Długość & F1 - wielkość rodziny (+) & 0,149 & 1,987 & 0,048 & \\
\hline \multirow[t]{2}{*}{ tułowia } & F2 - warunki bytowe & $-0,070$ & $-0,936$ & 0,350 & 1,7 \\
\hline & F3 - warunki stresowe & $-0,021$ & $-0,285$ & 0,766 & \\
\hline Długość koń- & F1 - wielkość rodziny & 0,128 & 1,729 & 0,086 & \\
\hline \multirow[t]{2}{*}{ czyn górnych } & F2 - warunki bytowe $(+)$ & 0,170 & 2,290 & 0,023 & 2,3 \\
\hline & F3 - warunki stresowe & 0,021 & 0,278 & 0,782 & \\
\hline Wskaźnik & F1 - wielkość rodziny & 0,135 & 1,826 & 0,700 & \\
\hline długości koń- & F2-warunki bytowe $(+)$ & 0,146 & 1,978 & 0,050 & 1,6 \\
\hline czyn górnych & F3 - warunki stresowe & 0,113 & 1,521 & 0,130 & \\
\hline \multirow[t]{3}{*}{ Obwód bioder } & F1 - wielkość rodziny & 0,100 & 1,339 & 0,182 & \\
\hline & F2 - warunki bytowe & $-0,071$ & $-0,946$ & 0,345 & 1,7 \\
\hline & F3 - warunki stresowe (-) & $-0,150$ & $-2,011$ & 0,046 & \\
\hline Tkanka & F1 - wielkość rodziny & $-0,011$ & $-0,149$ & 0,882 & \\
\hline tłuszczowa na & F2 - warunki bytowe (-) & $-0,151$ & $-2,027$ & 0,044 & 1,7 \\
\hline ramieniu & F3 - warunki stresowe & $-0,125$ & $-1,676$ & 0,096 & \\
\hline
\end{tabular}

Długość tułowia wykazuje dodatnią zależność z wielkością rodziny, co oznacza, że im większa rodzina (większa liczba osób w rodzinie), tym długość tułowia badanej młodzieży jest większa. Czynnik ten wyjaśnia zmienność długości tułowia w 1,7\%.

Długość kończyn dolnych wykazuje dodatni związek z czynnikiem zwanym „warunki bytowe”. Im lepsze warunki bytowe w rodzinie tym dłuższe kończyny dolne badanej młodzieży. Warunki bytowe wyjaśniają zmienność długości kończyn dolnych u badanej młodzieży w 2,3\%.

Wskaźnik kończyn górnych również wykazuje dodatni związek z czynnikiem „warunki bytowe”. Im lepsze warunki bytowe tym 
wskaźnik długości kończyn górnych jest większy (większa względna długość kończyn górnych w stosunku do wysokości ciała). Zmienność tego wskaźnika została wyjaśniona w 1,6\%.

Obwód bioder wykazuje ujemny związek ze stresem w domu i szkole (czynnik trzeci), co oznacza, że większym obwodem bioder charakteryzuje się młodzież, oceniająca stres w domu i w szkole, jako znikomy oraz wykazująca większą aktywność fizyczną. Zatem przy mniejszej stresowości życia i większej aktywności fizycznej młodzież ma mniejszy obwód bioder. Zmienność tej cechy została wyjaśniona przez czynnik trzeci (warunki stresowe) w 1,7\%.

Tylko jeden fałd skórno tłuszczowy (na ramieniu) wykazuje ujemny związek z czynnikiem „warunki bytowe”. W gorszych warunkach bytowych obserwuje się większe zasoby tkanki tłuszczowej na ramieniu niż w warunkach bytowych lepszych. Czynnik ten wyjaśnia zmienność fałdu skórno-tłuszczowego na ramieniu w 1,7\%.

\section{Dyskusja}

Z porównania wyników badań własnych warszawskiej młodzieży gimnazjalnej z danymi dotyczącymi ich rówieśników sprzed 14 lat (Palczewska, Niedźwiecka 2001: 1-120) wynika, że obie grupy młodzieży różnią się pod względem większości badanych cech. Młodzież współczesna, w porównaniu z młodzieżą badaną w latach 1996-99, posiada większą masę ciała oraz większy wskaźnik masy ciała (BMI). Natomiast nie wykazano różnic istotnych statystycznie pod względem wysokości ciała. Wielu autorów w swoich badaniach stwierdziło zwiększanie się zarówno wysokości, jak i masy ciała dzieci i młodzieży w czasie (Perenc 2009: 148-153, Bejer 2011: 10-24, Kowal et al. 2011: 37-44). Zjawisko takie dla młodzieży rzeszowskiej stwierdzono między latami 1976/80 i 1996/99, gdzie równocześnie zaobserwowano tendencje do smuklenia sylwetki, zwłaszcza u dziewcząt (Radochońska, Perenc 2006: 113-121), co jednak nie znalazło potwierdzenia w niniejszych badaniach. Badania porównawcze młodzieży rzeszowskiej na przestrzeni 25 lat, tj. w latach 1978/79, 1993/94 oraz 2003/04 wykazały zwiększanie się tak wysokości, jak i masy ciała u obu płci. Zmiany 
proporcji miedzy wysokością i masą ciała spowodowały u chłopców w wieku 3-6 lat smuklenie budowy ciała, natomiast w wieku 18 lat tendencję przeciwstawną. U dziewcząt proces smuklenia pojawił się dopiero między 16 a 18 rokiem życia (Perenc 2009: 148-153). Badania młodzieży bydgoskiej w latach 1979-1991 i poznańskiej w latach 1990-2000 nie wykazały jednak znacznych zmian w wysokości i masie ciała (Nowicki 2000: 119-125, Krawczyński 2003: 347-354). Długoletnie badania trendu sekularnego wysokości ciała, prowadzone przez Zakład Antropologii Polskiej Akademii Nauk we Wrocławiu, jednoznacznie wskazują na utrzymywanie się trendu sekularnego w populacji wrocławskiej. Stale obserwowane jest tam zwiększanie wysokości ciała mężczyzn w kolejnych dekadach (Kołodziej et al. 2015). Do podobnych wniosków doszli także badacze z innych krajów: w Tajlandii prowadzono badania nad rozwojem i dojrzewaniem dziewcząt. W badanej grupie zaobserwowano występowanie trendu sekularnego wysokości ciała i tempa dojrzewania dziewcząt (Jaruratanasirikul, Sriplung 2014: 1-8).

Badania prowadzone na Bałkanach w latach 1945-1995 także wskazują na zwiększanie się wysokości ciała mężczyzn. Badania te prowadzono na podstawie pomiarów kości długich ekshumowanych szkieletów. Pomimo różnic metodycznych, konkluzja badań pozostała zbieżna z wynikami innych autorów, którzy stwierdzają istnienie trendu sekularnego (Sarajlić et al. 2014: 209-213).

Badania własne nie potwierdzają powyższych obserwacji. Brak dalszego zwiększania się wysokości ciała młodzieży warszawskiej tłumaczyć można zróżnicowaniem tempa przemian sekularnych w tym samym czasie dla różnych populacji (Wolański 1990: 83-91). Zmiany sekularne są bardziej widoczne w tych grupach społecznych i populacjach, w których opóźnienia były największe. Najczęściej za przyczynę akceleracji uważa się postęp cywilizacyjny, z którym z kolei wiąże się poprawa sytuacji ekonomicznej (sposób odżywiania, warunki bytowania) oraz zwiększanie liczby bodźców docierających do ośrodkowego układu nerwowego. $\mathrm{Z}$ całą pewnością najbardziej sprzyjające warunki istnieją w ośrodkach wielkomiejskich. W wielu krajach europejskich, w ciągu ostatnich dziesięcioleci, zaobserwowano 
wyhamowanie dynamiki trendu. Uznano to za moment osiągnięcia takiej równowagi między potencjałem genetycznym populacji a warunkami środowiskowo-bytowymi, który umożliwia optymalną ekspresję genotypu. Stwierdzono więc, że przejawy fenotypowe akceleracji nie będą już dalej zachodziły (Radochońska, Perenc 2006: 113-121). Brak różnic w wysokości ciała w porównywanych grupach młodzieży może więc być wynikiem osiągnięcia równowagi opisanej powyżej. Innym wytłumaczeniem może być stabilizacja lub nawet pogorszenie warunków życia społeczeństwa, co mogło zahamować trend zwiększania wysokości ciała młodzieży.

W przypadku wskaźnika masy ciała (BMI), na przestrzeni lat można stwierdzić jego zwiększanie się, co związane jest także ze zwiększeniem masy ciała oraz grubości fałdów skórno-tłuszczowych, widocznych u młodzieży współczesnej (Gawlik et al. 2009: 19-27, Radochońska, Perenc 2006: 113-121). Potwierdzają to wyniki niniejszych badań: u badanej młodzieży obserwuje się istotnie większe BMI i większą grubość fałdów skórno - tłuszczowych w porównaniu $z$ rówieśnikami badanymi 14 lat temu. W literaturze są także doniesienia, wskazujące, że BMI na przestrzeni lat nie uległ istotnej zmianie (Kowal et al. 2011: 37-44). Badania krakowskie wykazały, że w ciągu trzydziestolecia (1971-2000), miał miejsce wzrost grubości fałdów skórno-tłuszczowych. Autorzy podkreślają jednak, że w ostatnim dwudziestoleciu tendencja ta jest coraz słabiej widoczna. Liczne doniesienia wskazują wręcz na zmniejszenie grubości fałdów skórno-tłuszczowych, przede wszystkim w starszych grupach wiekowych (Chrzanowska et al. 2002: 113-119, Kowal et al. 2011: 51-56). Wyniki te odbiegają od uzyskanych w niniejszych badaniach.

Badana współczesna młodzież warszawska charakteryzuje się większą długością tułowia oraz wskaźnikiem długości tułowia (do wysokości ciała) w porównaniu z młodzieżą badaną ponad dekadę temu. Podobne wyniki uzyskano dla populacji rzeszowskiej, gdzie na przestrzeni 25 lat stwierdzono zwiększenie się długości tułowia (Radochońska, Perenc 2010: 30-48). Badania własne wskazują także, że młodzież współczesna posiada krótsze kończyny dolne, tak w wymiarze bezpośrednim, jak i względnym (do wysokości ciała) 
w porównaniu z rówieśnikami z lat poprzednich. Nie znalazło to potwierdzenia $\mathrm{w}$ badaniach innych autorów: zarówno $\mathrm{w}$ populacji rzeszowskiej (Radochońska, Perenc 2010: 30-48), jak i w badaniach krakowskich (Kowal et al. 2011: 44-51): zaobserwowano wydłużenie kończyn dolnych i względnej ich długości.

W Polsce, wśród wielu czynników decydujących o dynamice rozwoju osobniczego i jego zróżnicowaniu, należy wymienić wielokierunkowe oddziaływanie środowiskowe SES. Jednym z nich są zmiany warunków życia (Cieślik et al. 1994: 7-257). Rodzice z wyższym wykształceniem mogą zapewnić swoim dzieciom wyższy standard życia, związany chociażby z lepszą organizacją wypoczynku, zdrowszym i bardziej racjonalnym odżywianiem, co wpływa korzystniej na ich rozwój zarówno funkcjonalny, jak i somatyczny (Charzewska et al. 1995: 7-144, Król 2004: 263-270, Pawlińska-Chmara, Kulik-Nowak 2005: 45-75, Zaworski 2005: 191-206, Bejer 2011: 10-24). Warunki bytowe wpływają na szereg cech budowy ciała. Najwięcej danych dotyczy ich wpływu na wysokość i masę ciała. Miarą SES są najczęściej: wykształcenie i zarobki rodziców, liczba osób w rodzinie, wielkość mieszkania oraz ma na to wpływ miejsce zamieszkania (wieś-miasto-teren uprzemysłowiony).

Wyniki badań własnych nie potwierdziły jednak zależności lepszych warunków bytowych z wysokością ciała warszawskich uczniów szkół gimnazjalnych, być może ze względu na zbyt małą liczebność tej próby i dużą liczbę rodziców z wyższym wykształceniem. Jednakże w literaturze potwierdzony pozostaje fakt, że dzieci pochodzące z lepszego SES są wyższe niż z gorszego SES (Jopkiewicz, Zaremba 2005: 81-91, Zaworski 2005: 191-206, Zadarko-Domaradzka, Tlałka 2007: 24-29, Fugiel et al. 2012: 32-38). Wielu autorów wskazuje na zależność wzrastania, wysokości ciała i tempa dojrzewania od warunków ekonomiczno-socjalnych (Jaruratanasirikul i Sriplung 2014: 1-8, Öberg 2014: 140-152)

Powodem obserwowanego zjawiska może być również fakt, że w ciągu ostatnich dekad warunki bytowe ulegają pogorszeniu dla większości społeczeństwa, jak również dotyczy to nawyków żywieniowych. Wysokość ciała jest bardzo czułym miernikiem zmian 
polityczno-społecznych wpływających na warunki społeczno-ekonomiczne. Obecnie dysponujemy danymi dla całej Warszawy (badania losowe prowadzone w 2012 i 2013), które potwierdzają obserwowane zjawisko dla młodzieży klas licealnych na Bielanach w Warszawie, związane z brakiem zwiększania się wysokości ciała na przestrzeni ostatnich 14 lat.

Wyniki niniejszej pracy wskazują, że w lepszych warunkach bytowych młodzież warszawska charakteryzuje się większą długością kończyn górnych i względną wielkością tego pomiaru oraz mniejszymi zasobami tkanki tłuszczowej w porównaniu z młodzieżą zaklasyfikowaną do gorszych warunków bytowych. Podobne wyniki badań na dzieciach i młodzieży uzyskano na terenie Podbeskidzia i Podkarpacia (Zdarko-Domaradzka, Tlałka 2007: 24-29). Wskazuje się także, że niski SES sprzyja otyłości i gromadzeniu się tłuszczu metabolicznie aktywnego w szczególności w okolicach brzucha (Mleczko, Szmigiel 2011: 81-98, Długosz et al. 2012: 858-863). Wyniki te nie znalazły potwierdzenia $\mathrm{w}$ niniejszej pracy: zaobserwowano, iż młodzież z rodzin o niższym statusie miała bardziej otłuszczone ramiona, nie zaobserwowano takich zależności dla fałdu na brzuchu.

Wyniki niniejszych badań wskazują, że młodzież pochodząca $z$ większych rodzin charakteryzuje się większą długością tułowia niż młodzież pochodząca $\mathrm{z}$ mniejszych rodzin, co jest zgodne $\mathrm{z}$ doniesieniami z literatury. Bielicki (1992: 3-18) stwierdził, że liczba osób $w$ rodzinie wpływa na proces wzrastania dzieci i młodzieży i istotnie go różnicuje. Lepsze warunki bytowe warunkują występowanie dłuższych kończyn, w szczególności dolnych, natomiast gorsze warunki bytowe sprzyjają rozwojowi tułowia, co ma związek z tendencją do ochrony narządów wewnętrznych, przed utratą energii (Wolański 2006: 270-281, 2012: 156-173). Większa liczba dzieci zmniejsza dochód przypadający na członka rodziny i powoduje, że spożycie artykułów żywnościowych na jedną osobę znacznie maleje (Kaczmarek 1995: 10-111, Jopkiewicz, Markowska 1999: 33-42).

Kolejnym czynnikiem badanym w niniejszej pracy, który wiązał się z warunkami bytowymi jest stres środowiskowy. Badania własne wykazały, że w warunkach bardziej stresowych (tak w domu, jak 
i w szkole oraz przy palących rodzicach) badana młodzież posiada mniejszy obwód bioder niż w warunkach mniej stresowych. Badania innych autorów wskazują, że nadmierny stres, niska aktywność fizyczna i nadmierna ekspozycja na dym tytoniowy są czynnikami powodującymi nadmierny przyrost masy ciała (Jodłowska et al. 2010: 127-134), a zatem można oczekiwać także większego obwodu bioder.

Badania zaprezentowane w niniejszej pracy są częścią wieloletnich obserwacji stanu biologicznego populacji polskiej. Zmieniające się warunki ekonomiczno-socjalne modyfikują przebieg rozwoju fizycznego człowieka. Dostępność i jakość produktów żywnościowych odbija się na zdrowiu i kondycji populacji. Jednym z mierników zdrowia jest wysokość ciała osiągana przez młodzież. Wieloletnie obserwacje zmian tej cechy stały się podstawą do diagnozy stanu biologicznego społeczeństwa. Badania te, choć powtarzane na przestrzeni lat, są cały czas źródłem informacji. Niniejsza publikacja jest kontynuacją tych obserwacji.

\section{Wnioski}

1. Badana młodzież charakteryzuje się odmienną budową i proporcjami ciała od młodzieży warszawskiej sprzed dekady. Różnic nie stwierdzono jedynie w przypadku wysokości ciała, co może wskazywać na stabilizację lub nawet pogarszanie się warunków bytowych i gorsze nawyki żywieniowe.

2. W lepszych warunkach bytowych badana młodzież posiada dłuższe kończyny górne (pomiar bezpośredni i względny - do wysokości ciała) oraz mniejsze zasoby tkanki tłuszczowej.

3. W większych rodzinach długość tułowia badanej młodzieży jest większa.

4. W warunkach bardziej stresowych (tak w domu jak i w szkole) badana młodzież posiada mniejszy obwód bioder niż w warunkach mniej stresowych. 


\section{Bibliografia}

Bejer A., 2011, Badania nad rozwojem fizycznym dzieci i młodzieży w południowo-wschodniej Polsce na przełomie XX i XXI wieku, Przegląd Medyczny Uniwersytetu Rzeszowskiego i Narodowego Instytutu Leków w Warszawie, 1, 10-24.

Bielicki T., 1992, Nierówności społeczne w Polsce w ocenie antropologa, Nauka Polska, 39, 3-18.

Cieśla E., Nowak-Starz G., 2007, Środowiskowe zróżnicowanie poziomu rozwoju morfofunkcjonalnego dzieci i młodzieży w wieku 10-16 lat, Studia Medyczne Akademii Świętokrzyskiej, Kielce, tom 8.

Cieślik J., Kaczmarek M., Kaliszewska-Drozdowska M. D., 1994, Dziecko Poznańskie'90, Wyd. Nauk. Bogucki, Poznań.

Charzewska J., Lewandowska J., Piechaczek H., Syta A., 1995, Społeczne uwarunkowania żywienia młodzieży w latach 1982-1991, Prace Instytutu Żywności i Żywienia, Warszawa, tom 71.

Chrzanowska M., Gołąb S., Żarów R., Sobiecki J., Matusik S., 2002, Trendy w otłuszczeniu ciała oraz występowanie nadwagi i otyłości wśród dzieci i młodzieży Krakowa w ostatnim trzydziestoleciu, Pediatria Polska 2, 113-119.

Długosz A., Niedźwiedzka E., Długosz T., Wądołowska L., 2012, Ocena wplywu sytuacji społeczno-ekonomicznej na występowanie centralnego otłuszczenia na podstawie wskaźnika talia-do-wysokości u młodzieży z małych miast i wsi w wieku 13-18 lat. Projekt Polyses, Bromatologia i Chemia Toksykologiczna XLV(3), 858-863.

Fugiel J., Sławińska T., Ignasiak Z., 2012, Ocena dyskryminacyjnej roli wykształcenia matki i dzietności rodzin w kształtowaniu wysokości ciała dzieci z zagłębia miedziowego, Medycyna Środowiskowa Environmental Medicine, 15(1), 32-38.

Gawlik A., Zachmurzok-Buczyńska A., Małecka-Tendera E., 2009, Powikłania otyłości u dzieci i młodzieży, Via Medica 5(1), 19-27.

Grzelak J., Nieczuja-Dwojacka J., 2013, Metody badań w antropologii (Skrypt dla studentów studiów licencjackich i uzupetniających na kierunku Biologia UKSW), Wydawnictwo UKSW, Warszawa. 
Jaruratanasirikul S., Sriplung H., 2014, Secular trends of growth and pubertal maturation of school children in Southern Thailand, Annals of Human Biology, 18, 1-8.

Jodłowska B., Ogińska H., Bilski J., Mańko G., 2010, Modele radzenia sobie ze stresem i cechy antropometryczne młodzieży gimnazjalnej, Public Health 45(2), 127-134.

Jopkiewicz A., Markowska M., 1999, Zróżnicowanie społeczne rozwoju fizycznego dzieci i młodzieży wiejskiej na Kielecczyźnie, w: „Uwarunkowania rozwoju fizycznego dzieci i młodzieży wiejskiej, Rocznik Naukowy IWFiS”, Biała Podlaska, VI(1), 33-42.

Jopkiewicz A., Zaręba M., 2005, Uwarunkowania rodzinne $i$ środowiskowe wysokości i masy ciała dzieci i młodzieży zamieszkałej na terenie różnych miast Kielecczyzny, Słupskie Prace Biologiczne, 1, 81-91.

Kaczmarek M., 1995, Wpływ warunków życia na wzrastanie i rozwój człowieka, Wydawnictwo Naukowe UAM, Poznań.

Kołodziej H., Łopuszańska M., Lipowicz A., Szklarska A., Bielicki T., 2015, Secular trends in body height and body mass in 19-year-old polish men based on six national surveys from 1965 to 2010, American Journal of Human Biology (on line version of record published before inclusion in an issue: http://www.readcube.com/articles/).

Kowal M., Cichocka B.A., Woronkowicz A., Pilecki MW., Sobiecki J., Kryst Ł., 2011, Międzypokoleniowe zmiany w budowie ciała i akceleracja pokwitania u dzieci i młodzieży w wieku 7-15 lat z populacji wielkomiejskiej wświetle uwarunkowań psychosocjalnych, w: M. Kowal i B.A. Cichocka (red.), „Monografie AWF”, Kraków, tom 5.

Krawczyński M., 2003, Kierunek zmian w rozwoju dzieci i młodzieży $w$ okresie dojrzewania na przełomie XX i XXI wieku w Polsce, Pediatria Polska, LXXVIII(50), 347-354.

Król H., 2004, Różnice środowiskowe w rozwoju cech somatycznych u chłopców i dziewcząt w okresie dojrzewania, Studia Medyczne Akademii Świętokrzyskiej, Kielce, 2, 263-270.

Malinowski A. 2002, Tendencja przemian rozwoju głowy u dzieci i młodzieży Poznania, w: A. Malinowski, J. Tatarczuk, R. Asienkiewicz (red.), „Ontogeneza i Promocja Zdrowia w Aspekcie Medycyny, 
Antropologii i Wychowania Fizycznego", Oficyna Wydawnicza Uniwersytetu Zielonogórskiego, Zielona Góra, 74-82.

Malinowski A., Wolański N., 1988, Metody Badań w Biologii Człowieka, Wydawnictwo Naukowe PWN, Warszawa.

Mleczko E., Szmigiel Cz., 2011, Otyłość i nadwaga dzieci i młodzieży $z$ Krakowa na tle wyników badań rówieśników z innych populacji, Antropomotoryka 21(45), 81-98.

Nowicki G., 2000, Secular changes of height and body mass of children and young in the Bydgoszcz region, Przegląd Antropologiczny 73, 119-125.

Öberg S., 2014, Long-term changes of socioeconomic differences in height among young adult men in Southern Sweden, 1818-1968, Economisc and Human Biology, 15, 140-152.

Palczewska I., Niedźwiecka Z., 2001, Wskaźniki rozwoju somatycznego dzieci i młodzieży warszawskiej, Medycyna Wieku Rozwojowego, 2, Supl. I.

Pawlińska-Chmara R., Kulik-Nowak D., 2005, Ocena budowy ciała dzieci w wieku 8-10 lat z powiatu Włoszczowa (województwo świętokrzyskie), Nowa Pediatria, 2, 45-75.

Perenc L., 2009, Rozwój somatyczny dzieci i młodzieży z Rzeszowa w świetle wspótczesnych badań, Young Sports Science of Ukraine 4, 148-153.

Przewęda R., 2009, Zmiany kondycji fizycznej polskiej młodzieży w ciagu ostatnich dekad, Studia Ecologiae et Bioethicae, 7(1), 57-71.

Radochońska A., Perenc L., 2006, Tendencja przemian w otłuszczeniu ciała u dzieci i młodzieży z Rzeszowa, Przegląd Medyczny Uniwersytetu Rzeszowskiego, 2, 113-121.

Radochońska A., Perenc L. 2008, Zmienność wybranych cech morfologicznych głowy w populacji dzieci i młodzieży rzeszowskiej w wieku od 3 do 18 lat w okresie 25-lecia, Przegląd Medyczny Uniwersytetu Rzeszowskiego, 2, 142-155.

Radochońska A., Perenc L., 2010, Zmiany proporcji budowy ciała dzieci i młodzieży rzeszowskiej $w$ wieku od 3-18 lat $w$ dwudziestopięcioleciu 1978-2004, Przegląd Medyczny Uniwersytetu Rzeszowskiego, $1,30-48$. 
Sarajlić N., Resić E., Gradaśćiević A., Salihbegović A., Balazic J., Zupanc T., 2014, Secilar trends in body height in Balkan populations from 1945 to 1995, Bosnian Journal of Basic Medical Sciences, 14(4), 209-213.

Wolański N., 1988, Czynniki i mechanizmy przemian międzypokoleniowych człowieka. cz. II., Przegląd Antropologiczny, 54, 1-2, 83-91

Wolański N., 2000, Proporcje ciała jako odzwierciedlenie warunków życia i stanu zdrowia, w: A. Malinowski, H. Stolarczyk, W. Lorkiewicz (red.), „Antropologia a medycyna i promocja zdrowia”, Wydawnictwo Uniwersytetu Łódzkiego, Łódź, 3, 191-209.

Wolański N., 2006, Ekologia człowieka, 1: Wrażliwość na Czynniki Środowiska i Biologiczne Zmiany Przystosowawcze, Wydawnictwo Naukowe PWN, Warszawa.

Wolański N., 2012, Rozwój Biologiczny Człowieka. Postawy Auksologii, Gerontologii i Promocji Zdrowia, Wydawnictwo Naukowe PWN, Warszawa.

Zadarko-Domaradzka M., Tlałka E., 2007, Wpływ czynników społeczno-ekonomicznych na zmienność wysokości i masy ciała dzieci, Przegląd Medyczny Uniwersytetu Rzeszowskiego, 1, 24-29.

Zaworski B., 2005, Kształtowanie się wybranych cech somatometrycznych dzieci kaszubskich na tle wpływu warunków społeczno-ekonomicznych ich rodzin, Słupskie Prace Biologiczne, 1, 191-206. 